\title{
Global Warming and Technologies for Carbon Capture and Storage
}

\author{
BULL, OS; BULL, I; AMADI, GK \\ Department of Chemistry, Rivers state University of Science and Technology, Nkpolu-Oroworukwo, Port Harcourt, Nigeria \\ *Corresponding Author Email: bullistics4real@yahoo.com
}

\begin{abstract}
Global concern about climate change caused by anthropogenic activities, such as the large scale use of fossil fuels as major energy sources for domestic and industrial application, which on combustion give off carbon dioxide $\left(\mathrm{CO}_{2}\right)$ into the atmosphere. Deforestation is also reducing one of the natural sinks for $\mathrm{CO}_{2}$. These anthropogenic activities have led to an increase in the concentration of $\mathrm{CO}_{2}$ in the atmosphere and have thus resulted in the warming of the earth's surface (Global Warming), droughts, melting of ice caps, and loss of coral reefs. Carbon capture and storage (CCS) and other variety of emerging technologies and methods have been developed. These technologies and methods are reviewed in this article.
\end{abstract}

\section{DOI: https://dx.doi.org/10.4314/jasem.v24i9.27}

Copyright: Copyright $(02020$ Bull et al. This is an open access article distributed under the Creative Commons Attribution License (CCL), which permits unrestricted use, distribution, and reproduction in any medium, provided the original work is properly cited.

Dates: Received: 10 August 2020; Revised: 16 September 2020; Accepted: 22 September 2020

Keywords: Global warming, carbon capture and storage, amine-based absorbents, Metal-Organic Frameworks

The sun is the major source of energy for the Earth's climate system compared to other sources of energy. An equilibrated climate system of the earth in terms of energy and concentration of greenhouse gases (GHGs) - carbon dioxide $\left(\mathrm{CO}_{2}\right)$, methane $\left(\mathrm{CH}_{4}\right)$, nitrous oxide $\left(\mathrm{N}_{2} \mathrm{O}\right)$, water vapour and other trace gases in the atmosphere implies that the amount of solar energy reaching the Earth's surface should be the same as the sum of the reflected solar radiation and infrared longwave radiation leaving the surface of the earth.

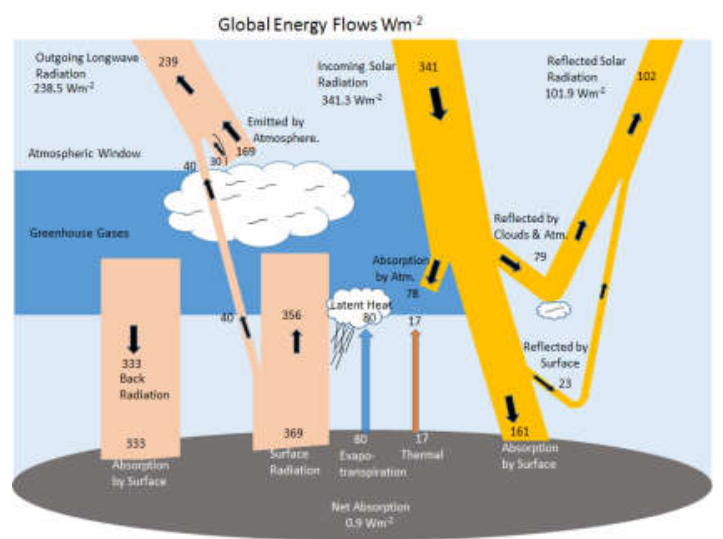

Fig 1: Global energy balance on annual-average basis (Figure adapted from ref.(Seinfeld, 2011))

A disruption of this global radiation arrangement and concentration of GHGs, be it natural or by human activities, brings about a radiation imbalance because GHGs are known to absorb infrared electromagnetic radiation and retain it on the surface of the Earth thus making the surface of the Earth warmer than it would otherwise be Figure 1 (Seinfeld, 2011; Kelvin, 2009).Globally, $85 \%$ of energy for domestic and industrialised application is generated using fossil fuels (crude oil, coal, natural gas) or fossil fuel power plants (Hanak et al., 2015; Rackley, 2010; Riboldi and Bolland, 2015). When fossil fuels are combusted in air for the purpose of generating energy, $\mathrm{CO}_{2}, \mathrm{H}_{2} \mathrm{O}$ and other greenhouse gases are also produced. Since the industrial revolution in ca. 1750,(Li et al., 2011) there has been the large scale use of fossil fuels and, of late, large scale deforestation which have caused an imbalance in the energy circle. The average Earth surface temperature has increased by more than $0.8^{\circ} \mathrm{C}$, an effect which has been most pronounced in the last four decades (Held, 2012; Seinfeld, 2011). Scientists believe that the major cause of the warmer surface of the Earth (global warming) is $\mathrm{CO}_{2}$, whose concentration in the atmosphere has been increasing steadily from the early years of the twenty-first century with a growth rate of ca. $2 \mathrm{ppm} /$ year as well as increasing overall from $270 \mathrm{ppm}$ at the beginning of the industrial revolution to about $403 \mathrm{ppm}$ at present (Choi et al., 2009; Lackner, 2010; Raupach et al., 2007) Figure 2. As can be seen in Figure 2, as the global concentration of $\mathrm{CO}_{2}$ increases the global temperature of the Earth's surface also increases. The increase of $\mathrm{CO}_{2}$ concentration in the atmosphere influences the balance of incoming and outgoing atmospheric energy of the Earth's system. The increase in $\mathrm{CO}_{2}$ concentration and warmer surface of

*Corresponding Author Email: bullistics4real@yahoo.com 
the Earth are widely believed to be due to anthropogenic activities such as the use of fossil fuels as a major source of energy which burns in air to give off $\mathrm{CO}_{2}$, as well deforestation and biomass decay.

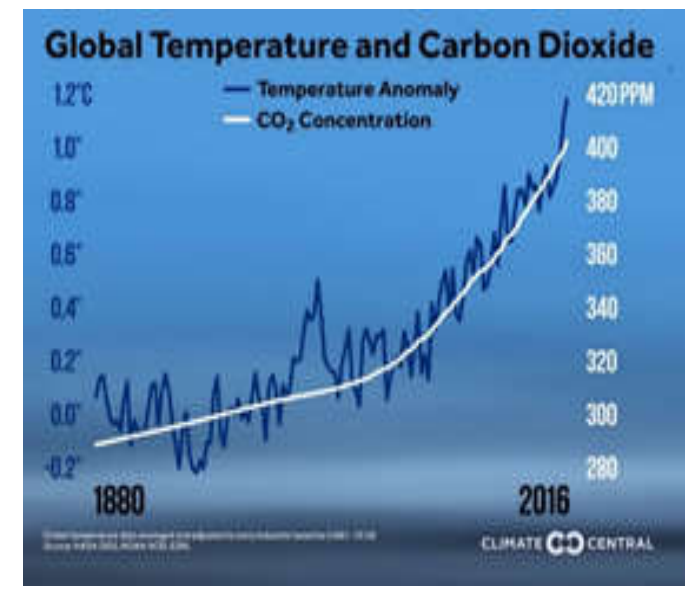

Fig 2: Global temperature and carbon dioxide; Global data average and adjusted to early industrial baseline (1881-1910), Source:

$$
\text { NASA GISS, NOAA NCEI, ESRL }
$$

Deforestation clears natural sinks for $\mathrm{CO}_{2}$ uptake whereas biomass decay leads to methane production and eventually $\mathrm{CO}_{2}$. The production of hydrogen from hydrocarbons via steam conversion and partial oxidation, has also contributed to $\mathrm{CO}_{2}$ concentration (Balat and Balat, 2009; Kalamaras and Efstathiou, 2012; Konieczny et al., 2008; Muradov, 1993; Onozaki et al., 2006; Rostrup-Nielsen and RostrupNielsen, 2002) Deforestation and the emission of these greenhouse gases into the atmosphere does not only lead to global warming, but are also associated with drought as well as serious health problems to humans and farm animals ( Li et al., 2003; Slaughter et al., 2005). Thus, globally it has become a task to reduce $\mathrm{CO}_{2}$ emissions while generating energy, chemical products, services, buildings and public infrastructure for the continuously rising population that is estimated to exceed nine billion by 2050 (United, Nations, 2008; United Nations: Department of Social and Economic Affairs; United Nations / Department of Economic and Social Affairs, 2009). With this in mind, $\mathrm{CO}_{2}$ chemistry, in particular with respect to its capture and storage, has attracted a great deal of attention in the past two and half decades in industry, the academic world, and the scientific community in general. Worldwide, concerted efforts are being made toward steadying $\mathrm{CO}_{2}$ concentration in the atmosphere. Some of these efforts include carbon mitigation technologies to moderate sources of $\mathrm{CO}_{2}$ emission and to promote carbon dioxide sinks. Some such approaches adopted so far include: increasing the efficiency of means of energy conversions and utilization, energy conservation in buildings by means of insulation and the use of alternative energy sources such as renewable energies (Bull and Obunwo, 2014) (hydroelectric-power, wind, solar, biofuels etc.) and nuclear energy. Other methods are the expansion of natural carbon sinks such as forests and soils to enhance their $\mathrm{CO}_{2}$ absorption capacities, as well as carbon sequestration.

Carbon Capture and Storage: Carbon Capture and Storage (CCS) from flue gas has gained growing interest in recent years in a bid to create a benign and sustainable energy economy. CCS is a three-part process: $\mathrm{CO}_{2}$ capture, $\mathrm{CO}_{2}$ separation from other flue gases, and transportation to a storage site or permanent storage. The technologies for conveyance and storage of $\mathrm{CO}_{2}$ are moderately mature and an increasing number of fully integrated CCS projects have got to the pilot and demonstration phases prior to commercialization (D'Alessandro et al., 2010; Figueroa et al., 2008; J. R. Li et al., 2011). Among the technologies used for $\mathrm{CO}_{2}$ storage are mineral sequestrations, in which the $\mathrm{CO}_{2}$ captured is pressurized and made to react with minerals underground and thus become part of the rock formation, or geological storage in which the $\mathrm{CO}_{2}$ captured is permanently stored in large underground stores as a gas as depicted in Figure 3 (Panel and Change, 2005).

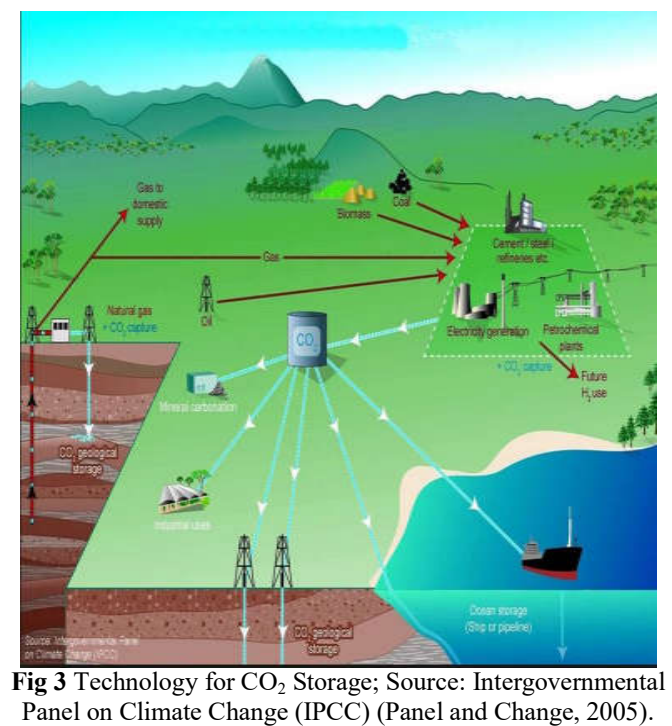

However, before the storage process, the $\mathrm{CO}_{2}$ has to be captured or separated from other flue gases. The capture of $\mathrm{CO}_{2}$ from source after the combustion of fossil fuels seems to be the most effective strategy for controlling anthropogenic $\mathrm{CO}_{2}$ release. In general, based on the fundamental chemical processes involved 
in fossil fuels combustion, the main $\mathrm{CO}_{2}$ capture possibilities are: pre-combustion, oxy-fuel combustion and post combustion capture (Feron and Hendriks, 2005; Rackley, 2010). In pre-combustion capture, a primary fuel (e.g. natural gas) reacts with oxygen or air at high temperature and pressure to give $\mathrm{CO}, \mathrm{CO}_{2}$ and $\mathrm{H}_{2}$. In some cases however, the produced gas mixture is mainly made up of $\mathrm{CO}$ and $\mathrm{H}_{2}$ (Synthesis gas) also known as syngas. The $\mathrm{CO}$ is further treated with steam in a catalytic reactor (shift converter) to produce more $\mathrm{H}_{2}$ (Equations $1 \& 2$ in Scheme 1)

$$
\begin{aligned}
& \mathrm{H}_{2} \mathrm{O}+\mathrm{CH}_{4} \longrightarrow 3 \mathrm{H}_{2}+\mathrm{CO} \\
& \mathrm{H}_{2} \mathrm{O}+\mathrm{CO} \longrightarrow \mathrm{H}_{2}+\mathrm{CO}_{2}
\end{aligned}
$$

Scheme 1: Equations (1) production of syngas, (2) production of further $\mathrm{H}_{2}$

The separation of $\mathrm{CO}_{2}$ and $\mathrm{H}_{2}$ can thereafter be achieved by other technologies. One of the advantages of pre-combustion capture is that the higher component concentrations and elevated pressures reduce the energy penalty of the process to about 10 $16 \%$ which is about half that of post-combustion $\mathrm{CO}_{2}$ capture (Eide and Bailey, 2005). Furthermore precombustion capture technology produces a $\mathrm{H}_{2}$-rich fuel, which can be used as a feedstock, in a fuel cell for power generation or in the improvement of a hydrogen economy. Oxy-fuel combustion on the other hand requires the use of nearly pure oxygen instead of air for the combustion of fuels. Oxy-fuel combustion produces nearly pure $\mathrm{CO}_{2}$ which can be stored directly. However, one of the drawbacks of this technique is that it requires pure oxygen and the pure oxygen is usually obtained from the separation of air or by other means. Post-combustion capture requires the stripping-off of $\mathrm{CO}_{2}$ from other flue gas comprising mainly $\mathrm{N}_{2}$ and $\mathrm{CO}_{2}$ before release into the atmosphere. This method of $\mathrm{CO}_{2}$ capture is the most feasible in the short time scale because most of the proposed technologies can be retrofitted to the existing fossil fuel consuming power plants. One of the new methodologies involves the use of cooled and $\mathrm{CO}_{2}$ rich flue gases to feed the bioreactor to produce microbial biomass that would be utilised as a biofuel. In post-combustion capture even if the $\mathrm{CO}_{2}$ capture unit is shut down due to an emergency, electricity can still be generated. This is not possible with precombustion and oxy-fuel combustion captures. The post-combustion capture method has been deployed commercially and primarily for the separation of minor contaminants such as $\mathrm{Hg}, \mathrm{SO}_{\mathrm{x}} / \mathrm{NO}_{\mathrm{x}}$ gases, however, the sorbent for $\mathrm{CO}_{2}$ removal requires some modification of the power plant with respect to high preparation and regeneration cost Figure 4 (Feron, and Hendriks, 2005; Figueroa et al., 2008; Rackley, 2010) is a diagrammatic representation of the three methods for $\mathrm{CO}_{2}$ capture from power generation plant. However, within the three methods for $\mathrm{CO}_{2}$ capture described above, there are further techniques for the separation of $\mathrm{CO}_{2}$ from other light gases. These subheadings fall into five different approaches. These approaches are cryogenic distillation, membrane purification, absorption with liquids, adsorption based on solid materials and chemical looping, Figure 5 (D'Alessandro et al., 2010; Figueroa et al., 2008; Li et al., 2011)
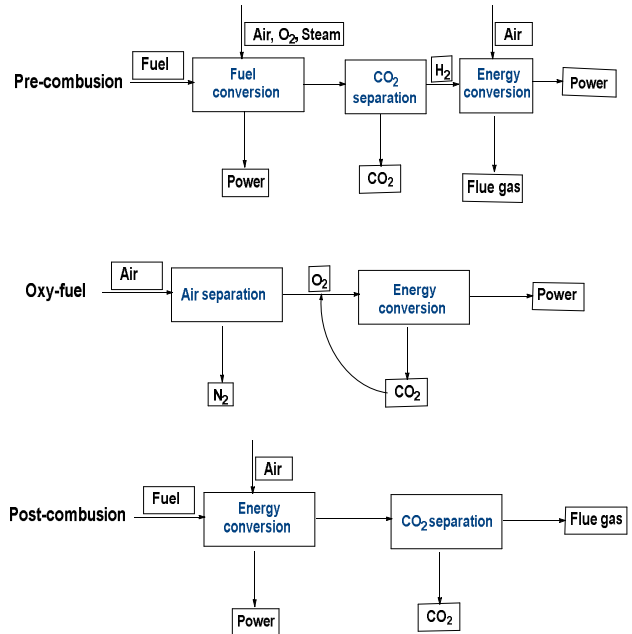

Fig 4: Three methods for $\mathrm{CO}_{2}$ capture from power generation plan.

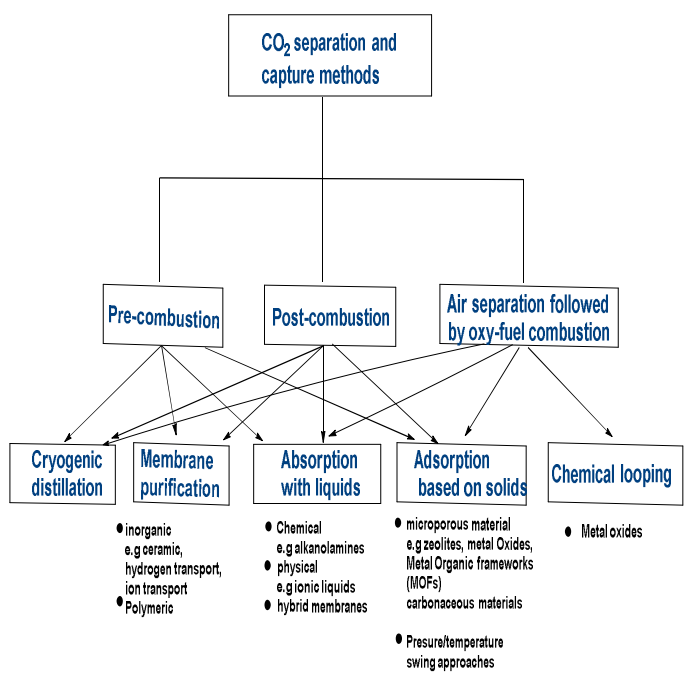

Fig 5: Materials for $\mathrm{CO}_{2}$ capture in the context of pre-combustion, post-combustion and oxy-fuel captures

Cryogenic distillations are widely used for other gas separations but are not practically viable for $\mathrm{CO}_{2}$ separations from flue gases because of the high energy cost. For relatively concentrated sources of $\mathrm{CO}_{2}$, e.g. from natural gas deposits, extensive studies have been done (e.g. the use of membranes). Membranes are 
most effective as mass-separation agents when the species that are to pass through them are in high concentration. Thus, in pre-combustion capture in which $\mathrm{CO}_{2}$ is well known to be a minor component of the off-gases, membranes are not likely to be good candidates for efficient separation. However, for processes such as post-combustion capture in which there is a relatively high concentration of $\mathrm{CO}_{2}$ stream at elevated temperature, membranes are good candidates.

Amine Based Absorbents: Absorption of $\mathrm{CO}_{2}$ with liquids is usually carried out with solvents containing aqueous amine solutions such as monoethanolamine (MEA), diethanolamine (DEA) or methyldiethanolamine (MDEA). They are considered to be state-of-the-art due to their efficiency of up to $98 \% \mathrm{CO}_{2}$ capture from flue gases. These aqueous amine solutions provide high absorption rates and capacities for $\mathrm{CO}_{2}$ through the nucleophilic attack of the amine (Choi et al., 2009) functional group on $\mathrm{CO}_{2}$ to give a carbamate or bicarbonate molecule as shown below in Scheme 1 (Rochelle, 2009; Shakerian et al., 2015; Yu et al., 2012) The reaction mechanism for the reaction between $\mathrm{CO}_{2}$ and primary or secondary amine based solvents begin with the formation of a zwitterion followed by the attack of a base [:B] to abstract a proton $\left(\mathrm{H}^{+}\right)$from the zwitterion. The base molecule could be water, hydroxyl ion or an amine functional group while $R_{1}$ and $R_{2}$ are substituents such as alkyl or hydrogen

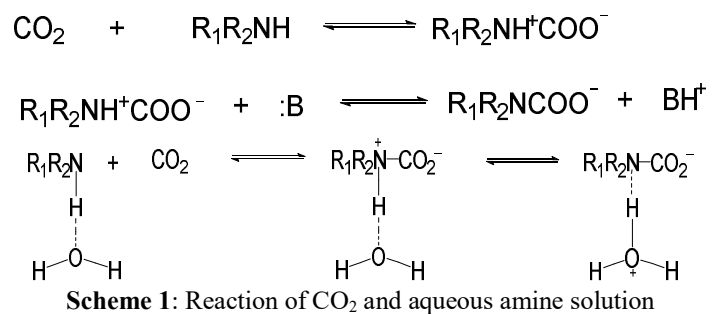

This mechanism implies that, in the first step; $\mathrm{CO}_{2}$ interacts with the hydrated amine molecule via hydrogen bonding of the oxygen of water to form the intermediate zwitterion. The zwitterion is weakly bonded to the water molecule, hence in the second step, a base molecule attacks to deprotonate the zwitterion. The zwitterion is thus an intermediate species formed by this proposed mechanism (Caplow, 1968) One of the assumptions of this mechanism is that a hydrogen bonding is formed between the amine and the base $\left(\mathrm{H}_{2} \mathrm{O}\right)$ followed by the reaction of the $\mathrm{CO}_{2}$. However, others have proposed a single step termolecular mechanism as shown below in Scheme 2 (Crooks and Donnellan, 1989). This pathway implies that no zwitterion is formed and the breaking and formation of old and new bonds between $\mathrm{CO}_{2}$, amine and the base (B) all take place in a concerted manner.

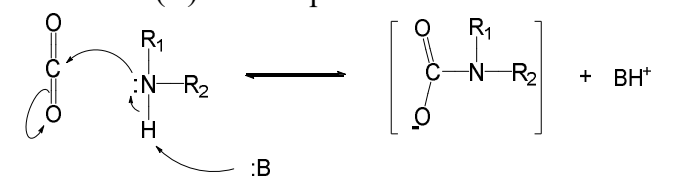

Scheme 2: Pathways interaction of $\mathrm{CO}_{2}$ and amine

However, be it through the zwitterion or termolecular mechanisms discussed above, a carbamate is formed. The carbamate formed undergoes a hydrolysis to give bicarbonate, Scheme 3.

\section{$\mathrm{R}_{1} \mathrm{R}_{2} \mathrm{NCOO}^{-}+\mathrm{H}_{2} \mathrm{O} \rightleftharpoons \mathrm{R}_{1} \mathrm{R}_{2} \mathrm{NH}+\mathrm{HCO}_{3}^{-}$}

Scheme 3: Hydrolysis of carbamate to bicarbonate

Tertiary amine solvents on the other hand do not react directly with $\mathrm{CO}_{2}$ to give carbamates the way primary and secondary amine solvents do. This is because, tertiary amine solvents lack a reactive $\mathrm{N}-\mathrm{H}$ group. They usually react by acting as a base to catalyse the hydration of $\mathrm{CO}_{2}$ in the presence of $\mathrm{H}_{2} \mathrm{O}$ to give a bicarbonate as exemplified with an alkanolamine shown below in Scheme 4.

$$
\begin{aligned}
& \mathrm{CO}_{2}(\mathrm{aq})+\mathrm{H}_{2} \mathrm{O} \rightleftharpoons \mathrm{H}_{2} \mathrm{CO}_{3} \\
& \mathrm{CO}_{2}(\mathrm{aq})+\mathrm{OH}^{-} \rightleftharpoons \mathrm{HCO}_{3}^{-}
\end{aligned}
$$

$\mathrm{CO}_{2}+\mathrm{H}_{2} \mathrm{O}+\mathrm{R}_{1} \mathrm{R}_{2} \mathrm{R}_{3} \mathrm{~N} \rightleftharpoons \mathrm{R}_{1} \mathrm{R}_{2} \mathrm{R}_{3} \mathrm{~N}^{+} \mathrm{H}+\mathrm{HCO}_{3}^{-}$

Scheme 4: Base catalysed hydration of $\mathrm{CO}_{2}$ to bicarbonate

The reaction involves the lone pair of electrons on the nitrogen acting as a Lewis base enabling the alkanolamine to be bonded to the water molecule via hydrogen bonding and thus driving the reaction between the water and $\mathrm{CO}_{2}$ to give hydrogen carbonate. Since pKa plays an important role in the absorption of $\mathrm{CO}_{2}$ by amine based solvents, tertiary amines such as triethanolamine $\left(\mathrm{pKa}=7.76\right.$ at $\left.25^{\circ} \mathrm{C}\right)$ will most likely decrease the absorption capacity of this amine solvent compared to primary amine solvents. However, it has been reported that tertiary amines require less energy for their regeneration as well as remaining intact after several regeneration cycles (Lin and Shyu, 2000; Reza and Trejo, 2006). In the post-combustion removal of $\mathrm{CO}_{2}$ from the flue gas stream in the natural gas industry, the most widely used amine based solvent system is the MEA absorption process. In this absorption process, the MEA solution is required to be in contact with the flue gas in an absorber column, reacting with $\mathrm{CO}_{2}$ to form MEA carbamate in solution. The $\mathrm{CO}_{2}$ rich MEA solution is then sent to a stripper where the solution is 
reheated to regenerate pure $\mathrm{CO}_{2}$ (Stewart and Hessami, 2005). However, this process is capital intensive as it requires a high energy input for absorbent regeneration as well as large process units. The heating cost during the solvents' regeneration is estimated to be up to $70 \%$ of the total cost of operating a $\mathrm{CO}_{2}$ capture plant (Espinal and Morreale, 2012; Idem et al., 2006) In view of all the difficulties associated with amine based absorption solvents, better $\mathrm{CO}_{2}$ capture systems are rapidly required for advancing $\mathrm{CCS}$ technologies.

Porous Materials for Adsorption: Adsorption processes for gases using solid adsorbent are well known (Berlier and Frère, 1996; Cavenati, 2004; D'Alessandro et al., 2010; Li et al., 2012; Li et al., 2011; Martín et al., 2011; Merel et al., 2008; Puthiaraj et al., 2015; Rangnekar et al., 2015). At a low pressure, $\mathrm{CO}_{2}$ behaves like $\mathrm{N}_{2}$ and $\mathrm{Ar}$ in terms of its adsorption on non-porous solid surfaces, following closely to the Langmuir model. Thus in theory, a solid-state adsorbent with a high Brunauer-Emmett-Teller (BET) surface area will have a high $\mathrm{CO}_{2}$ adsorption capacity as well as a high adsorption aptitude for other gases like $\mathrm{N}_{2}, \mathrm{H}_{2} \mathrm{O}$ and other flue gases due to non-selective adsorption. This implies that the adsorption capability of an adsorbent toward $\mathrm{CO}_{2}$ will be reduced significantly if the amount of $\mathrm{CO}_{2}$ in a mixture of gases is low. The percentages of $\mathrm{CO}_{2}$ in a typical flue gas from coal-fired or gas-fired station are only approximately $13 \%$ and $8 \%$ respectively (Hasan et al., 2012). In a bid to attain a high $\mathrm{CO}_{2}$ separation efficiency, adsorbents for post-combustion capture need to have a high selectivity for $\mathrm{CO}_{2}$ over $\mathrm{N}_{2}$ and $\mathrm{H}_{2} \mathrm{O}$ present in the gas stream. Two common strategies are employed in a bid to design proficient adsorbents for $\mathrm{CO}_{2}$. These strategies are: targeting the physical property of $\mathrm{CO}_{2}$ in terms of its molecular dimensions, and exploiting its chemical properties. Size exclusion can be used to separate $\mathrm{CO}_{2}$ from flue gas stream. This is based on the variance in molecular dimensions of the gas components in the flue gas mixture (Li et al., 2011; Sneddon et al., 2014). Size exclusion takes advantage of the permeability theory and is mainly applied to separate larger molecules in the liquid phase, such as dialysis for the purification of biomolecules (Sneddon et al., 2014). But its application in the separation for $\mathrm{CO}_{2}$ depends greatly on the size, shape, connectivity and topography of the pores of an adsorbent solid to create a stronger interface towards a specific target component in the mixture due to the close proximity of the surface to the target gas molecules (Krishna and van Baten, 2010). One family of microporous crystalline materials known as zeolites have been extensively used for this purpose due to their unique pore size/structure. Other microporous materials such as carbon nanomaterials and Metal-Organic
Frameworks (MOFs) possessing distinctive pore dimensions are also capable of this kind of separation (Verdegaal et al., 2016). Advantage can also be taken from the chemical properties of $\mathrm{CO}_{2}$ for selective adsorption. Carbon dioxide can be considered as a weak acid. As a weak acid it can react readily with a base to give carbamates and bicarbonates as shown in Scheme 5.

$$
\begin{aligned}
& \mathrm{CO}_{2}+2 \mathrm{MOH} \longrightarrow \mathrm{M}_{2} \mathrm{CO}_{3}+\mathrm{H}_{2} \mathrm{O} \\
& \mathrm{CO}_{2}+2 \mathrm{R}_{1} \mathrm{R}_{2} \mathrm{NH} \rightleftharpoons \mathrm{R}_{1} \mathrm{R}_{2} \mathrm{NCOO}^{-}+\mathrm{R}_{1} \mathrm{R}_{2} \mathrm{NH}_{2} \\
& \mathrm{CO}_{2}+\mathrm{H}_{2} \mathrm{O}+2 \mathrm{R}_{1} \mathrm{R}_{2} \mathrm{NH} \rightleftharpoons \mathrm{HCO}_{3}^{-}+\mathrm{R}_{1} \mathrm{R}_{2} \mathrm{NH}_{2}^{+} \\
& \text {Scheme 5: Formation of a carbamate and bicarbonate via the } \\
& \text { reaction of } \mathrm{CO}_{2} \text { and inorganic metal hydroxide }[\mathrm{MOH} \text { is an } \\
& \text { inorganic Metal hydroxide (a base)] }
\end{aligned}
$$

In a flue gas stream components such as $\mathrm{N}_{2}$, unreacted $\mathrm{O}_{2}, \mathrm{H}_{2} \mathrm{O}$ and hydrocarbons are neutral, as such, adsorbents of basic functionalities can selectively adsorb acidic gas such as $\mathrm{CO}_{2}$. However, in a typical flue gas stream, $\mathrm{CO}_{2}$ is not the only acidic component, other components such as $\mathrm{SO}_{2}$ (a major component if the flue gas has a high sulphur content) and NOx are also acidic. Thus, increasing the concentration of these two acidic gases in the flue gas stream will reduce the efficiency of the $\mathrm{CO}_{2}$ separation. In addition, the adsorption strength of the $\mathrm{CO}_{2}$ onto the basic adsorbents should not be too strong as this would cause problems for the downstream removal of $\mathrm{CO}_{2}$ and the regeneration of the adsorbents' active sites.(Espinal and Morreale, 2012). The adsorption of $\mathrm{CO}_{2}$ on solid materials works through weak physisorption or chemisorption interaction and is mostly employed in cyclic, multi-module processes of adsorption and desorption in which desorption is induced by pressure or temperature swing (Choi et al., 2009) Activated carbons, alkaline earth metal-oxides, hydrotalcites,(Bhatta et al., 2015) supported amines,(Shakerian et al., 2015; Yu et al., 2012) zeolites, (Krishna and van Baten, 2010). Covalent Organic Frameworks (COFs) (Diaz and Corma, 2016; Olajire, 2017) as well as MOFs (Zhou et al 2012; Sabouni et al., 2014; Verdegaal et al., 2016) are all examples of this class of adsorbents (Li et al., 2017; Sumida et al., 2012) Activated carbons have been reported to have a $\mathrm{CO}_{2}$ uptake of $4 \mathrm{mmol} / \mathrm{g}$ and a selectivity of $\mathrm{CO}_{2} / \mathrm{N}_{2}$ near 10 at room temperature and 1 bar (Berlier and Frère, 1996). However, activated carbons are negatively affected by the presence of moisture. This is because of water's ability to competitively adsorb with respect to $\mathrm{CO}_{2}$. Although most activated carbons with hydrophobic features reduce these effects, under humid conditions their adsorption capacities are still reduced due to gradual 
oxidation of the carbon surface brought about by the presence of water.

Alkaline earth metal oxides are also known to adsorb $\mathrm{CO}_{2}$. A mole of the metal oxide has the ability to react with a stoichiometric equivalent of $\mathrm{CO}_{2}$ exothermically to give a metal carbonate as shown below in Scheme 6.

$$
\begin{aligned}
& \mathrm{MO}(\mathrm{s})+\mathrm{CO}_{2} \longrightarrow \mathrm{MCO}_{3}(\mathrm{~s}) \\
& \text { Where } \mathrm{M}=\mathrm{Mg}, \mathrm{Ca}, \mathrm{Sr} \text {, or Ba. }
\end{aligned}
$$

Scheme 6: Reaction of $\mathrm{CO}_{2}$ with alkaline earth metal oxides

The calcium minerals are the most abundant of all the alkaline earth metal oxides in nature. They occur commonly in nature in the form of carbonates such as limestone or dolomite and when heated to high temperature they liberate $\mathrm{CO}_{2}$ and form calcium oxide. Hence $\mathrm{CaO}$ represents an already available $\mathrm{CO}_{2}$ adsorbent as shown below (Equation 3 Scheme 7) (unfortunately however, it releases $\mathrm{CO}_{2}$ when it is formed).

\section{$\mathrm{CaO}(\mathrm{s})+\mathrm{CO}_{2}(\mathrm{~g}) \longrightarrow \mathrm{CaCO}_{3}(\mathrm{~s})$ (exothermic process) \\ $\Delta \mathrm{H}=-179 \mathrm{~kJ} / \mathrm{Mol}$}

The decomposition of the $\mathrm{CaCO}_{3}$ (s) liberates $\mathrm{CO}_{2}$ as shown in (Equation 4):

$$
\begin{aligned}
& \mathrm{CaCO}_{3(\mathrm{~s})} \longrightarrow \mathrm{CaO}(\mathrm{s})+\mathrm{CO}_{2}(\mathrm{~g}) \text { (endothermic process) } \\
& \Delta \mathrm{H}=+179 \mathrm{~kJ} / \mathrm{Mol}
\end{aligned}
$$

Scheme 7: Equations (3) absorption of $\mathrm{CO}_{2}$ on $\mathrm{CaO}$ to give $\mathrm{CaCO}_{3}$ (4) decomposition of $\mathrm{CaCO}_{3}$ to liberate $\mathrm{CO}_{2}$

In general the uptake capacity of alkaline earth metal oxides is based on a stoichiometric reaction. For basic absorbents using neutralization, the maximum $\mathrm{CO}_{2}$ uptake capacity can also be estimated stoichiometrically if $100 \%$ efficiency is assumed. For instance, the $\mathrm{CO}_{2}$ adsorption capacity of calcium oxide $\mathrm{CaO}$ in the equation above can be estimated using the formula:

$$
\% \mathrm{CO}_{2} \mathrm{AE}(\mathrm{mmol} / \mathrm{g})=\frac{S / \% \mathrm{CO}_{2} \mathrm{SR}}{F W S} \times 100
$$

Where $\mathrm{AE}$ adsorption efficiency, $\mathrm{S}=$ sorbent, $\mathrm{SR}=$ stoichiometric ration and FWS = formula weight of sorbent

Thus the maximum theoretical amount of $\mathrm{CO}_{2}$ adsorbed by $\mathrm{CaO}$ is $17.8 \mathrm{mmol} / \mathrm{g}$. However, typical capacities reported in the literature (e.g. $13.4 \mathrm{mmol} / \mathrm{g}$ for micrometer-sized particles $(10 \mu \mathrm{m}))$ (Barker, 1974) are much lower than this ideal value.(Choi et al., 2009) The $\mathrm{CO}_{2}$ adsorptions by $\mathrm{CaO}$ and $\mathrm{MgO}$ are approximately 17.86 and $25 \mathrm{mmol} / \mathrm{g}$ of sorbent respectively but the regeneration of the latter requires less energy (Espinal and Morreale, 2012).

Thus, using this method, the maximum theoretical capacity of all bases - liquids or solids can be estimated. For ammonium hydroxide solution $(\approx 30 \%$ $\mathrm{w} / \mathrm{w}$ ) the maximum $\mathrm{CO}_{2}$ adsorption capacity is 8.8 $\mathrm{mmol} / \mathrm{g}$, while beryllium oxide $(\mathrm{BeO})$ solid is 37.0 $\mathrm{mmol} / \mathrm{g}$, which is probably the material with the highest theoretical $\mathrm{CO}_{2}$ adsorption capacity via neutralization. Unfortunately, these estimations assume a $100 \%$ stoichiometric reaction which is unlikely to occur, particularly for solid, and nonporous adsorbents such as $\mathrm{CaO}$, due to the accessibility of sites. Therefore, the experimental values are usually much lower. In the case of amine adsorbents, the assumption is usually made, that two amine groups will react with one molecule of $\mathrm{CO}_{2}$ to form the more stable carbamate species as shown in Scheme 8.

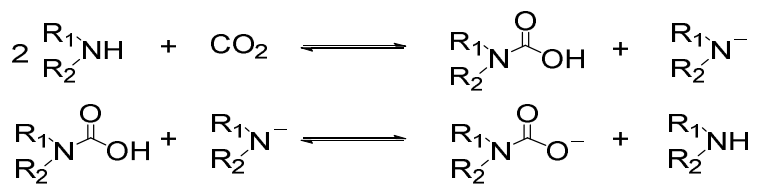

Scheme 8: A two-step pathway for the formation of carbamate from amines and $\mathrm{CO}_{2}$

Thus, the ratio of nitrogen/carbon dioxide $\left(\mathrm{N}_{2} / \mathrm{CO}_{2}\right)$ gives a certain degree of indication on how efficient an amine-based adsorbent is. But the efficiency of $\mathrm{CO}_{2}$ uptake capacity of an adsorbent can be determined from the experimental and theoretical maximum adsorption capacity as follows:

$$
\% A E=\frac{E C}{T M C} x 100
$$

Where AE adsorption efficiency, EC = experimental capacity and $\mathrm{TMC}=$ theoretical maximum capacity

Such calculations and estimations give indication of how many basic sites, such as the number of amine groups on an adsorbent, are actively interacting with $\mathrm{CO}_{2}$ molecules. Hydrotalcites, have a general formula $\mathrm{Mg}_{6} \mathrm{Al}_{2} \mathrm{CO}_{3}(\mathrm{OH})_{16} .4\left(\mathrm{H}_{2} \mathrm{O}\right)$ and are generally anionic clays that are also suitable sorbents for $\mathrm{CO}_{2}$ in temperature ranges of $400-500{ }^{\circ} \mathrm{C}$. Impregnation of the hydrotalcite materials with $\mathrm{K}_{2} \mathrm{CO}_{3}$ has been reported to improve their $\mathrm{CO}_{2}$ sorption (Feng et al., 2007; Hutson et al., 2004). Both alkaline earth metal oxides 
and hydrotalcite materials degrade after several cycles. However, the regeneration of hydrotalcites can be enhanced via some variation in the calcination step (Reddy et al., 2006). Oxides of lithium such as $\mathrm{Li}_{2} \mathrm{ZrO}_{3}$ and $\mathrm{Li}_{4} \mathrm{SiO}_{4}$ have also been reported to show great prospects for high temperature $\mathrm{CO}_{2}$ uptake (Kato et al., 2005; Ochoa-Fernández et al., 2006). Zeolite materials have also been reported to adsorb $\mathrm{CO}_{2}$ in greater capacities than activated carbons (Chue et al., 1995; Hauchhum and Mahanta, 2014; Langlois et al., 2016). Zeolites are natural or synthetic hydrated aluminosilicate minerals made from linked tetrahedra of alumina $\left(\mathrm{AlO}_{4}\right)$ and silica $\left(\mathrm{SiO}_{4}\right)$ that have relatively porous three-dimensional crystalline structures (Xu et al., 2007). Generally zeolites contain alkali or alkaline-earth metals with a general chemical composition of $\mathrm{M}_{\mathrm{nx}} / \mathrm{nSi}_{1-\mathrm{x}} \mathrm{Al}_{\mathrm{x}} \mathrm{O}_{2} \cdot \mathrm{yH}_{2} \mathrm{O}$. Where $\mathrm{M}$ could be $\mathrm{Na}^{+}, \mathrm{K}^{+}, \mathrm{Li}^{+}, \mathrm{Ag}^{+}, \mathrm{NH}_{4}^{+}, \mathrm{H}^{+}, \mathrm{Ca}^{2+}, \mathrm{Ba}^{2+}$ etc. Zeolite $13 \mathrm{X}$ (a bench-mark zeolite) has a $\mathrm{CO}_{2}$ uptake of up to $7.4 \mathrm{mmol} / \mathrm{g}$ with a higher selectivity of $\mathrm{CO}_{2}$ over $\mathrm{N}_{2}$ than activated carbons (Merel et al., 2008; Yuan et al., 2012). However, zeolites also have the problem of requiring higher regeneration temperatures (Berlier and Frère, 1996; Dunne et al., 1996). Enzymebased systems have also been reported to have potential for $\mathrm{CO}_{2}$ capture. Carbozyme Inc. has developed biomimetic technology in which a $0.5 \mathrm{~m}^{2}$ Carbozyme permeator fed with $15.4 \% \quad \mathrm{CO}_{2}$ feed stream successfully separated $85 \%$ of the $\mathrm{CO}_{2}$ (Trachtenberg et al., 2009). Thus is a significant improvement over the use of amine-based solvents for $\mathrm{CO}_{2}$ absorption process. This strategy of $\mathrm{CO}_{2}$ uptake derives its origin from natural occurring reactions of $\mathrm{CO}_{2}$ in living organisms (Lindskog and Coleman, 1973; Silverman and Lindskog, 1988). A biologicalbased system mimics the mechanism of the mammalian respiratory system to capture $\mathrm{CO}_{2}$ and release as shown in Figure 6.

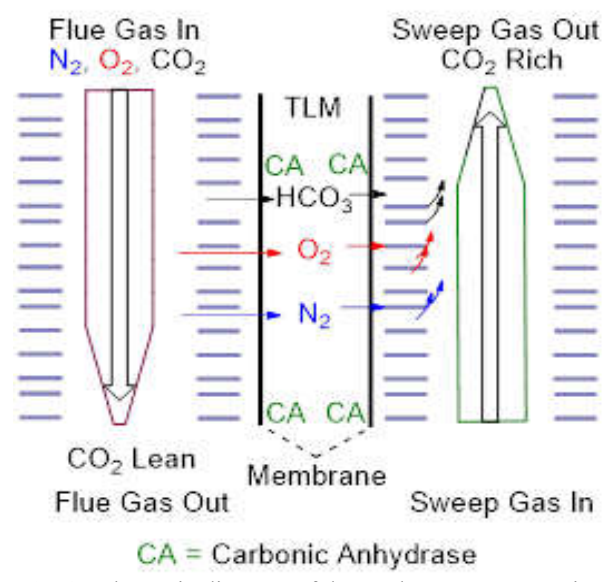

Fig 6: Schematic diagram of the Carbozyme permeation process.(adapted from Trachtenberg et al., 2009)
The Carbozyme permeator is made up of three key components: (a) a rapid catalyst $(\mathrm{CA}=$ Carbonic Anhydrase), (b) a high efficiency mass transfer hollow fiber and (c) and low energy (low energy steam).(Figueroa et al., 2008; Trachtenberg et al., 2009) The two hollow fiber chambers are separated by a microporous membrane which contains a thin liquid membrane (TLM). The CA is attached to the wall of the hollow fiber to ensure that all $\mathrm{CO}_{2}$ entering the hollow fiber gets in contact with the $\mathrm{CA}$ at the gas liquid interface to obtain the highest conversion efficiency. The resistance encountered by the gases as they travel through the microporous membrane is low. This implies that $\mathrm{CO}_{2}$ faces minimal diffusion resistance before its conversion to bicarbonate at the feed side. The rate at which $\mathrm{CO}_{2}$ dissolves in water is hindered by its aqueous hydration. In addition, the $\mathrm{CO}_{2}$ carrying capacity of water is also limited by the buffering capacity of water. Thus the addition of the enzyme CA to the solution speeds up the rate at which carbonic acid is formed.(Shekh et al., 2012) This means that $\mathrm{CA}$ serves as a catalyst by facilitating the conversion of $\mathrm{CO}_{2}$ to carbonate while the liquid film restricts the entrance of nitrogen and oxygen.

Experimentally, one molecule of CA has been found to have the capacity to catalyze the hydration of 600,000 molecules of $\mathrm{CO}_{2}$ per second compared to a theoretical 1,400,000 maximum rate.(Figueroa et al., 2008) Thus the quantity of enzymes needed for this process is small as a result of the turnover rate. It has been reported that CA process has a low heat of absorption. This implies that the energy penalty associated with biological-based $\mathrm{CO}_{2}$ absorption processes is reduced compared to MEA-based solvent processes. The Carbozyme biomimetic process looks promising; but the use of enzyme based systems has some technical challenges such as membrane boundary layer, poor mass transfer, instant backward dehydration, pore wetting, surface fouling, loss of enzyme activity over long time operation, and problems associated with scaling-up (Bao and Trachtenberg, 2006; Figueroa et al., 2008; Yadav et al., 2014). Covalent-Organic Frameworks (COFs) have been reported as porous materials with promising applications in areas such as gas storage and adsorption where lightweight materials are desired (Furukawa and Yaghi, 2009). COF-108 (Bull, 2020; El-Kaderi et al., 2007) for example has been reported to have a density as low as $0.17 \mathrm{~g} / \mathrm{cm}^{3}$ as well as possessing $4.7 \mathrm{~nm}$ diameter hexagonal pores (Spitler et al., 2011). In addition, MOFs such as MOF- 210 (surface area $6240 \mathrm{~m}^{2} / \mathrm{g}$ ) and MOF-177 (surface area of $4500 \mathrm{~m}^{2} / \mathrm{g}$ ) have been reported to possess a $\mathrm{CO}_{2}$ uptake potential of $2870 \mathrm{mg} / \mathrm{g}$ at $298 \mathrm{~K} / 55 \mathrm{bar}$, and $33.5 \mathrm{mmol} / \mathrm{g}$ at $32 \mathrm{bar}$ respectively.(Espinal and 
Morreale, 2012; Farha et al., 2012; Millward and Yaghi, 2005) MOFs are made of metal based nodes connected by organic bridging ligands or "struts" and assemble principally by strong co-ordinate bonds under mild conditions which results in crystalline 1, 2, or 3-D materials (Davies et al., 2012; Timokhin et al., 2013) with uniform pore diameters typically in the range of $3-20 \AA$.

Compounds Derived From Borosilicate/Organoboron Lewis Acids And Pyridines: $\mathrm{Si}-\mathrm{O}-\mathrm{B}$ and O-B-O containing compounds abound in the literature (Daniel and Alan, 1992) and the Si-O, B-O and C-O bond energies are 452,536 and $358 \mathrm{~kJ} / \mathrm{mol}$ respectively. Thus the $\mathrm{Si}-\mathrm{O}$ and the $\mathrm{B}-\mathrm{O}$ bonds are stronger than typical $\mathrm{C}-\mathrm{O}$ bond energy. A good number of these compounds possess and display unusual high elasticity when a stress is suddenly applied, as well as high plasticity when the stress is applied slowly (O'Dowd et al., 1993). These Si-O-B and O-B-O containing compounds exist in the form of metaboric, boronic acid, six-, eight- or ten-membered cages, cycloborosiloxane derivatives or borosilicate cage as well as large rings as shown in Figure 7 (Brisdon et al., 1992; Daniel and Alan, 1992).

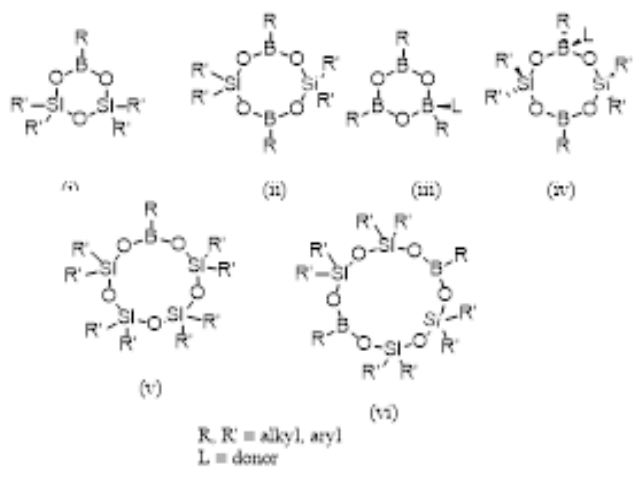

Figure 7: Structures of (i) Cyclo-boratrisiloxane; (ii) Cyclodiboratetrasiloxane; (iii) 1:1 adduct of a boroxine; (iv) 1:1 adduct of a cyclo-diboratetrasiloxane; (v) 10-membered cycloboratetrasiloxane; (vi) 12-membered cyclo-

diboratetrasiloxane.(Brisdon et al., 1992; Daniel and Alan, 1992)

Borosilicate scaffolds have promising applications as building blocks in supramolecular chemistry. However, they have only been marginally exploited. For example, (Hunt et al., 2008) and (Mirela, and Ruggi, 2013) reported the use of a 8-membered borosilicate cage whose nodes were used for the synthesis of a 3-D system (COF-202) and macrocycles respectively. Liu et al., (2009) used the same principle for the synthesis of $\pi$-extended polymeric borosilicate cages used as sensors for volatile organic amines. (Gopalakrishnan et al., 2016) reported the synthesis, structure, photophysical and other calculations on series of eight-membered cyclic-borarasiloxanes wherein the crystal packing pattern displayed noncovalent interactions. Recently, the synthesis of cyclic and cage-like borosilicates based on boronic acid and potential application in assemblies of triphenylboroxine and piperazine was reported (Torres-Huerta et al., 2017). Irrespective of the myriad of applications of borosilicates and borosilicate adducts, only a few synthetic strategies for cyclic and cagelike molecular borosilicates and adducts are known. The reason for this may mainly be as a result of: (I) the number of commercially available silanols are few, (II) structural modifications of these compounds are difficult, (III) issues associated with stability (Hernández-Balderas, 2017). The basic methods used in the syntheses of these borasiloxanes rings involve the cyclocondensation reaction of appropriate organoboronic acids and Si-containing precursors such as dihydroxysiloxanes, diethoxysilanes, and $\alpha, \omega$-dihydrosiloxanes as well as the condensation of dichlorophenylborane with dihydroxysilanes (Beckett et al., 1997; Beckett et al., 2000; Daniel and Lough, 1992). Solvents used include dry toluene, triethylamine, sodiumdriedbenzene or a mixture of solvents under a nitrogen atmosphere in which water is continuously removed by the use of a Dean-Stark apparatus as these reactions are readily reversible. Some reactions for the syntheses of these compounds are shown in Scheme 9.

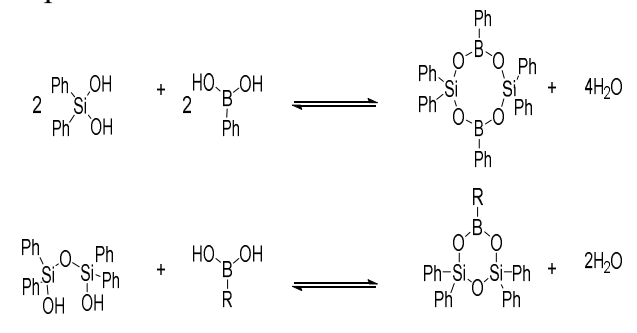

$$
\begin{aligned}
& \text { Scheme 9: Pathways for the syntheses of cyclic 8- and 6- } \\
& \text { membered ring Si-O-B compounds }
\end{aligned}
$$

However, in the absence of diols, boronic acids also undergo self-condensation reaction. The reversible reaction nature of boronic acids that lead to the formation of boroxines enables formation of reversible molecular assemblies.(Icli et al., 2011) For example, the self-condensation of boronic acids to give boroxines of 6-membered ring $\mathrm{B}_{3} \mathrm{O}_{3}$ structures is a powerful tool for the building of molecular assembly, (Icli et al., 2011) as shown in Scheme 10. 


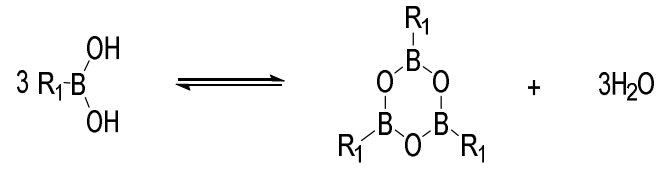

Scheme 10: Self-condensation of boronic acids.(Icli et al., 2011)

Apart from the fact that boronic acids can form covalent bonds via condensation, they also have the potential to interact non-covalently via hydrogen bonding. Thus, hydroxyl functional group in boronic acids can act as hydrogen bond donors which enables the formation of supramolecular self-assembly in the solid state. Most of these boron-based compounds in the literature contain three coordinated B centres in which the boron has a vacant $\mathrm{p}$-orbital and as such are Lewis acidic in character. Gutman and co-workers described a quantitative parameter called acceptor number (AN) as a measure of solvent Lewis acidity. The acceptor number scale arbitrarily assigns fixed points 0 and 100 to hexane and $\mathrm{SbCl}_{5}$ respectively. On the same scale $\mathrm{BF}_{3}$ has a value of 89 (Beckett et al., 1996). Thus the relative reactivity of Lewis bases such as amines toward boratrisiloxanes and diboratetrasiloxanes is dependent on the acceptor number which has a close relationship with the electronic environment. Cyclo-diboratetrasiloxanes have acceptor number values between 46-62 and are termed as moderately strong Lewis acids comparable to triorganoboroxines with acceptor numbers of approximately 50 (Beckett et al., 2000) On the other hand cyclo-boratrisiloxanes have considerably lower AN values, ranging from 22-28 which are comparable to trialkylorthoborate esters with ANs in the range (1830) (Beckett et al., 1996). Thus, the acceptor number plays a pivotal role in determining whether a $\mathrm{B}-\mathrm{O}-\mathrm{Si}$ containing compound can form an isolable adduct on reaction with a Lewis base such as amines or not. For example whereas triorganoboroxines (AN approximately 50) forms isolable amine (cyclohexylamine, 4-methylpyridine, 3methylpyridine, piperidine, morpholine, isobutylamine, methylamine) (Beckett et al., 1995) adducts, trialkylorthoborate esters AN (18-30) generally do not form isolable amine adducts (Lappert, 1956). The Lewis acidity of borasiloxane ring systems depend on the degree of electron density offered to the $\mathrm{B}$ from adjacent $\mathrm{O}$ atom and on the organic substituent on the $\mathrm{B}$ atom. The boron in these O-B-O compounds is $\mathrm{sp}^{2}$ hybridized, and can bind with Lewis bases $(\mathrm{N}$ donors, O-donors)(Höpfl, 1999; Kua et al., 2006) as ligands as shown Scheme 11.

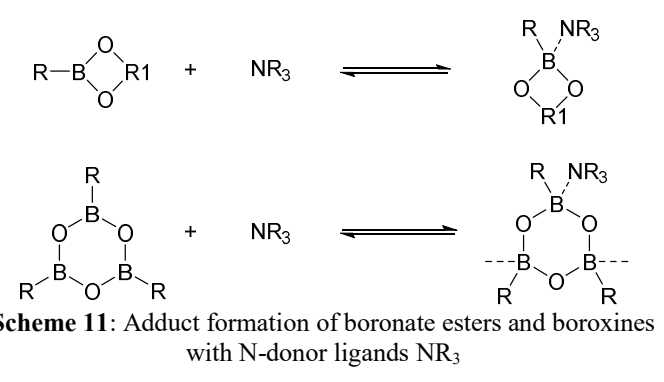

However, the $\mathrm{B} \cdots \mathrm{N}$ bonds are less stable than the corresponding B-O covalent bonds. For adducts of boronate esters, the N-B bond energy is approximately 15 to $25 \mathrm{~kJ} / \mathrm{mol}$,(Bosch et al., 2004) whereas a computational estimated value of $13 \mathrm{~kJ} / \mathrm{mol}$ has been reported by (Franzen et al., 2003) That notwithstanding, the formation of tetracoordinated boron adducts is important in non-polar organic solvents.(Ferguson et al., 2007) The N-B bond has been employed in recognition processes(Celis et al., 2014) as well as in the construction of macrocycles,(Barba et al., 2004; Barba et al., 2013; Barba and Betanzos, 2007; Salazar-Mendoza et al., 2008; Sheepwash et al., 2013) polymericsystems,(Christinat, Croisier, et al., 2007; Sheepwash et al., 2011) rotaxanes(Christinat et al., 2008) and lately organic cage compounds.(Dhara and Beuerle, 2015; Icli et al., 2011) For instance, the reaction of boronic acids with tridentate imine ligands derived from salicylaldehyde and aminoalcohols has been reported in the literature to give macrocycles(Barba et al., 2004; Barba et al., 2001; Sa et al., 2002) Scheme 12.

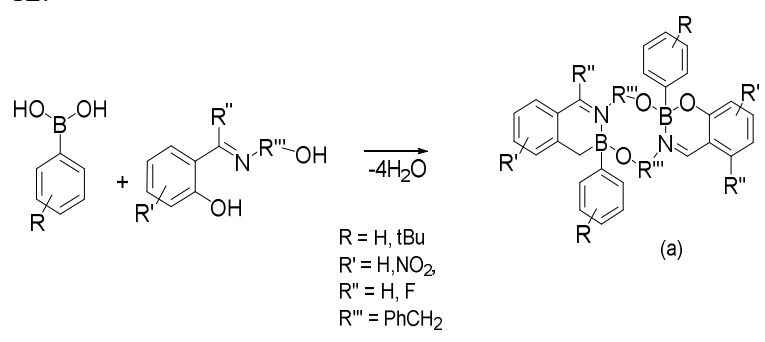

Scheme 12: Formation of a macrocycle via a condensation reaction.(V Barba et al., 2004; Sa et al., 2002)

The reactions of 3-aminophenylboronic acid with substituted salicylaldehyde, 2-hydroxyacetatophenone or 2-hydrobenzophenone have also been reported to give a calix[3] arene-like macrocycles(Barba et al., 2004) such as the one in Scheme 13. 


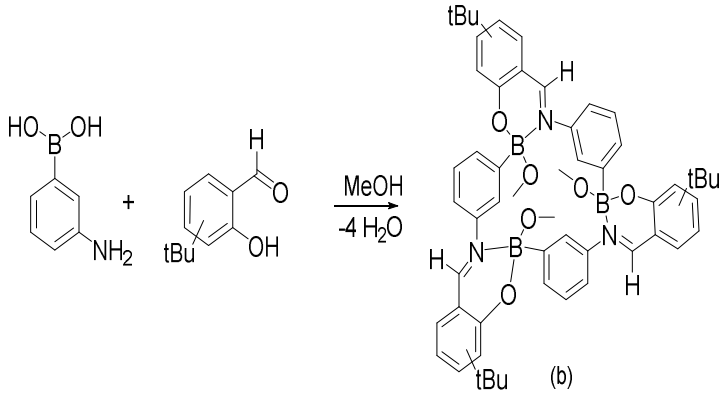

Scheme 13: Formation of calix[3] arene-like macrocycle (b).(Barba et al., 2004)

Arylboronic acids have also been reported(Santillan et al., 2005) to react with 2,6-dimethylethanolpyridine to give [4+4] condensation products as shown in Scheme 14.

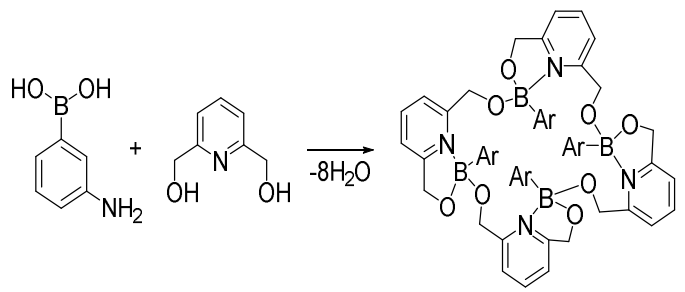

(c)

Scheme 14: Formation [4+4] condensation product from arylboronic acids.(Santillan et al., 2005)

These macrocycles - (a), (b) and (c), are all made up of covalent organic frameworks with O-B-O connections. However, boronate ester reactions can also result in macro-cyclisation initiated by B-N bonds. For example, the reaction of boronic acids with 2,3- or 3,4-dihydroxypyridine ligands give tetrameric (d)(Victor Barba et al., 2001) and pentameric (e)(Christinat, Scopelliti, et al., 2007) macrocycles respectively as shown in Scheme 15.

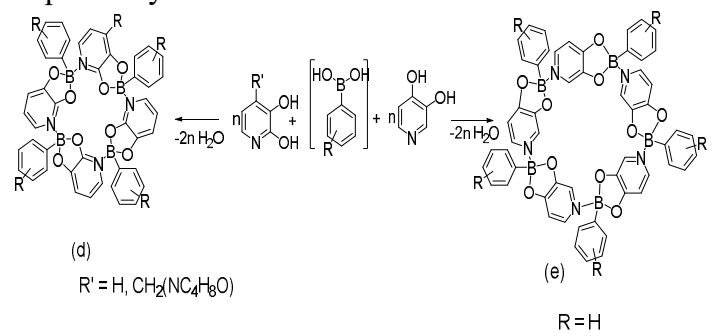

Scheme 15: Formation of tetrameric(Victor Barba et al., 2001) and pentameric macrocycles.(Christinat, Scopelliti, et al., 2007)

Furthermore, Severin and coworkers(Icli et al., 2012) obtained a 1-D polymer, connected via a dative B-N bond and a macrocycle by the condensation of pyridyl ligands alongside other precursors and 1,4bis(benzodioxaborole)benzenes as shown in Scheme 16.

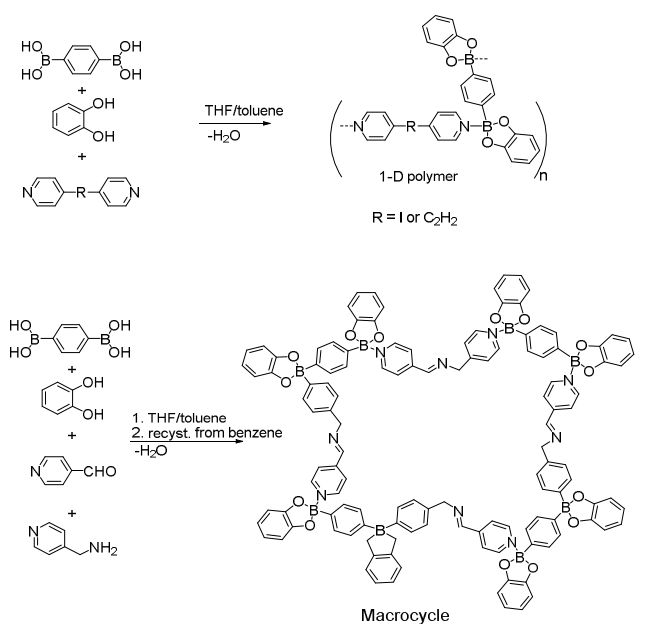

Scheme 16: Syntheses of 1-D polymer and macrocycle from their respective monomers.(Icli et al., 2012)

2-D and 3-D structures with these type of assemblies based on literature search have not been prepared. In addition, borosilicate ring compounds have been studied little for the formation of 1-D, 2-D or 3-D polymeric structures.

Conclusion: Anthropogenic activities such as large scale used of fossil fuels for domestic, and industrial application has resulted global warming. In this review article, research publications geared toward the mitigation of global warming, $\mathrm{CO}_{2}$ capture and related gas absorption and adsorption, gas separation in MOFs and COFs have been carried out. We hope that this review article will assist researchers to follow the global trend.

Acknowledgement: We thankfully acknowledge the financial support given to us by the Nigerian Government through the Petroleum Technology Development Fund (PTDF), Nigeria, as well as the Rivers State University, Port Harcourt Nigeria

\section{REFERENCES}

Torres-Huerta, A; Velásquez-Hernández, MJ; Ramírez-Palma, LG; Cortés-Guzmán, F; Martínez-Otero, D; Hernández-Balderas U; Jancik V (2017). Synthesis of Cyclic and Cage Borosilicates Based on Boronic Acids and Acetoxysilylalkoxides. Experimental and Computational Studies of the Stability Di ff erence of Six- and Eight-Membered Rings. Inorg. Chem, 56(16): 10032-10043.

Balat, M (2009). Political, economic and environmental impacts of biomass-based hydrogen. Int. J. Hydrog. Energy, 34(9), 35893603 
Bao, L; Trachtenber; MC (2006). Facilitated transport of $\mathrm{CO}_{2}$ across a liquid membrane: Comparing enzyme, amine, and alkaline. J. Membr. Sci. 280(1-2): 330-334.

Barba, V; Hopfl, H; Farfan, N; Santillan, R; Beltran, HI; Zamudio-Rivera, LS (2004). Boron-nitrogen macrocycles: a new generation of calix 3 arenes. ChemComm. 24(24): 2834-2835.

Barba, V; Betanzos, I (2007). Direct synthesis of polymacrocyclic boron compounds. A convenient method for the synthesis of hemicarcerands. $J$. Organomet Chem. 692(22), 4903-4908.

Barba, V; Gallegos, E; Santillan, R; Farfán, N (2001). New boron macrocycles based on self-assembly of Schiff bases. J. Organomet. Chem. 622(1-2): 259-264.

Barba, V; Ramos, P; Jiménez, D; Rivera, A; Meneses, A (2013). Calixarene and hemicarcerand-like compounds obtained by self-assembly of 3aminophenylboronic acid and salicylaldehyde derivatives. Inorg Chim Acta, 401, 30-37.

Barker, R. (1974). The reactivity of calcium oxide towards carbon dioxide and its use for energy storage. J. Appl. Chem. Biotech. 24(4-5): 221227.

Beckett, MA; Hibbs, DE; Hursthouse, MB; Malik, KMA; Owen, P; Varma, KS (2000). cycloBoratrisiloxane and cyclo-diboratetrasiloxane derivatives and their reactions with amines: crystal and molecular structure of $\left(\mathrm{p}-\mathrm{BrC}_{6} \mathrm{H}_{4}\right.$ $\mathrm{BO})_{2}\left(\mathrm{Ph}_{2} \mathrm{SiO}\right)_{2}$. J. Organomet. Chem. 595(2): 241-247.

Beckett, MA; Strickland, GC; Holland, JR; Varma, KS (1996). A convenient n.m.r. method for the measurement of Lewis acidity at boron centres: Correlation of reaction rates of Lewis acid initiated epoxide polymerizations with Lewis acidity. Polymer, 37(20): 4629-4631.

Beckett, MA; Strickland, GC; Varma, KS; Hibbs, DE; Hursthouse, MB; Malik, KMA (1997). Amine adducts of triarylboroxines: Synthesis and characterization of adducts of tri(2-tolyl) boroxine and crystal structures of $\left(4-\mathrm{MeC}_{6} \mathrm{H}_{4}\right)_{3} \mathrm{~B}_{3} \mathrm{O}_{3}$ and (4$\left.\mathrm{MeC}_{6} \mathrm{H}_{4}\right) \quad 3 \mathrm{~B}_{3} \mathrm{O}_{3} \cdot$ 4-picoline. J. Organomet. Chem. 535(1-2), 33-41.

Beckett, MA; Strickland, GC; Varma, KS; Hibbs, DE;
Hursthouse, MB; Malik, KMA. (1995). Synthesis And Characterization Of Amine Adducts Of Tri ( 4-Tolyl ) Boroxine And Tri ( 3, 5- Xylyl ) Boroxine : Molecular Structure Of (4-Mecom4 ) Ab303 " Cyclohexylamine. Polyhedron. 14(19): 2623-2630.

Berlier, K; Frère, $\mathrm{M}$ (1996). Adsorption of $\mathrm{CO}_{2}$ on Activated Carbon: Simultaneous Determination of Integral Heat and Isotherm of Adsorption. $J$. Chem Eng Data, 41(5): 1144-1148.

Bhatta, LKG; Subramanyam, S; Chengala, MD; Bhatta, UM; Venkatesh, K (2015). Enhancement in $\mathrm{CO}_{2}$ Adsorption on Hydrotalcite-based Material by Novel Carbon Support Combined with $\mathrm{K}_{2} \mathrm{CO}_{3}$ Impregnation. Ind. Eng. Chem. Res. 54(43): 10876-10884

Bosch, LI; Fyles, TM; James, TD (2004). Binary and ternary phenylboronic acid complexes with saccharides and Lewis bases. Tetrahedron, 60(49): 11175-11190

Brisdon, BJ; Mahon, MF; Molloy, KC; Schofield, PJ (1992). Synthesis and structural characterization of cycloborasiloxanes: the X-ray crystal structures. J. Organomet. Chem. 436, 11-22.

Bull, OS (2020). Solvothermal synthesis and characterization of a new 3D potassium MetalOrganic Framework (MOF) structure. J. Chem. Soc. Nigeria, 45(1): 126-134.

Bull, OS; Obunwo, CC (2014). Bio-Diesel Production from Oil of Orange ( Citrus Sinensis ) Peels as Feedstock. J. Appl. Sci. Environ. Manage. 18(3): 371-374.

Caplow, M (1968). Kinetics of Carbamate Formation and Breakdown. J. Am. Chem. Soc., 90(24), 67956803

Cavenati, S (2004). Adsorption equilibrium of Methane, Carbon Dioxide and Nitrogen on Zeolite $13 \mathrm{X}$ at high pressures. J. Chem. Eng Data. 49: 1095-1101.

Celis, NA; Godoy-Alcántar, C; Guerrero-Álvarez, J; Barba, V (2014). Boron macrocycles based on multicomponent assemblies using (3aminophenyl)boronic acid and pentaerythritol as common reagents; Molecular receptors toward lewis bases. EurJIC. 2014(9), 1477-1484.

Choi, S; Drese, JH; Jones, CW (2009). Adsorbent 
materials for carbon dioxide capture from large anthropogenic point sources. ChemSusChem, 2(9): 796-854.

Christinat, N; Croisier, E; Scopelliti, R; Cascella, M; Röthlisberger, U; Severin, K (2007). Formation of boronate ester polymers with efficient intrastrand charge-transfer transitions by three-component reactions. EurJIC. 2007(33): 5177-5181.

Christinat, N; Scopelliti, R; Severin, K (2007). Multicomponent assembly of boron-based dendritic nanostructures. JOC. 72(6): 2192-2200.

Christinat, N; Scopelliti, R; Severin, K (2008). Boronbased rotaxanes by multicomponent selfassembly. Chem Comm. 31(31), 3660.

Chue, KT; Kim, JN; Yoo, YJ; Cho, SH; Yang, RT (1995). Comparison of Activated Carbon and Zeolite $13 \mathrm{X}$ for $\mathrm{CO}_{2}$ Recovery from Flue Gas by Pressure Swing Adsorption. Ind. Eng. Chem. Res. 34(2), 591-598.

Crooks, JE; Donnellan, JP (1989). Kinetics and mechanism of the reaction between carbon dioxide and amines in aqueous solution. J. Chem. Soc., Perkin Trans 2. 2(4): 331-333.

D’Alessandro, DM; Smit, B; Long, JR (2010). Carbon dioxide capture: Prospects for new materials. Angew Chem. Int. Ed. 49(35): 6058-6082

Daniel A. Foucher, Alan J. Lough, I. M. (1992). Synthesis, Properties, and Ring-Ring Transformation Reactions of Cyclic Siloxanes Incorporating Skeletal Boron Atoms: X-ray Crystal Structures of the Strained Boracyclotrisiloxane $(\mathrm{PhBO})\left(\mathrm{Ph}_{2} \mathrm{SiO}\right)_{2}$ and the Boracyclotetrasiloxane $(\mathrm{PhBO})\left(\mathrm{Ph}_{2} \mathrm{Si} 0\right)_{3}$. Inorg. Chem. 31(9): 3034-3043.

Davies, RP; Lickiss, PD; Robertson, K; White, AJP (2012). An organosilicon hexacarboxylic acid and its use in the construction of a novel metal organic framework isoreticular to MOF-5. CrystEngComm, 14(3): 758.

Dhara, A; Beuerle, F (2015). Reversible Assembly of a Supramolecular Cage Linked by BoronNitrogen Dative Bonds. Chem. Eur J. 21(48): 17391-17396.

Diaz, U; Corma, A (2016). Ordered covalent organic frameworks, COFs and PAFs. From preparation to application. Coord. Chem. Rev. 311: 85-124.
Dunne, JA; Rao, M; Sircar, S; Gorte, RJ; Myers, AL (1996). Calorimetric Heats of Adsorption and AdsorsSption Isotherms .2. $\mathrm{O}_{2}, \mathrm{~N}_{2}, \mathrm{Ar}, \mathrm{CO}_{2}, \mathrm{CH}_{4}$, $\mathrm{C}_{2} \mathrm{H}_{6}$, and $\mathrm{SF}_{6}$ on NaX, H-ZSM-5, and Na-ZSM5 Zeolites. Langmuir. 12(26): 5896-5904.

Eide, LI; Bailey, DW (2005). Precombustion Decarbonisation Processes. Oil \& Gas Science and Technology - Rev. IFP, 60(3): 475-484. https://ogst.ifpenergiesnouvelles.fr/articles/ogst/p

El-Kaderi, HM; Hunt, JR; Mendoza-Cortés, JL; Côté, AP; Taylor, RE; O’Keeffe, M; Yaghi, OM (2007). Designed synthesis of 3D covalent organic frameworks. Science, 316(5822), 268-272:

Espinal, L; Morreale, BD (2012). Materials challenges in carbon-mitigation technologies. MRS Bulletin, 37(04): 431-438.

Farha, OK; Eryazici, I; Jeong, NC; Hauser, BG; Wilmer, CE; Sarjeant, AA; Snurr, RQ; Nguyen, ST; Yazaydin, AÖ; Hupp, JT (2012). Metalorganic framework materials with ultrahigh surface areas: Is the sky the limit. J. Am. Chem. Soc. 134(36): 15016-15021.

Feng, B; An, H; Tan, E (2007). Screening of $\mathrm{CO}_{2}$ adsorbing materials for zero emission power generation systems. Energy Fuels. 21(2): 426-

Ferguson, G; Lawrence, SE; Neville, LA; O’Leary, BJ; Spalding, TR (2007). Synthetic and X-ray diffraction studies of borosiloxane cages $\left[\mathrm{RSi}(\mathrm{ORBO})_{3} \mathrm{SiR}\right]$ and the adducts of $\left[\mathrm{ButSi}\{\mathrm{O}(\mathrm{PhB}) \mathrm{O}\}_{3} \mathrm{SiBut}\right]$ with pyridine or $\mathrm{N}, \mathrm{N}, \mathrm{N}, \mathrm{N}$-tetramethylethylenediamine.

Polyhedron, 26(12): 2482-2492.

Feron, PHM; Hendriks, CA (2005). $\mathrm{CO}_{2}$ capture process principles and costs. Oil Gas Sci. Tech. 60(3): 451-459.

Figueroa, JD; Fout, T; Plasynski, S; McIlvried, H; Srivastava, RD (2008). Advances in $\mathrm{CO}_{2}$ capture technology-The U.S. Department of Energy's Carbon Sequestration Program. Int. J. Greenhouse Gas Contr. 2(1): 9-20.

Franzen, S; Ni, W; Wang, B (2003). Study of the Mechanism of Electron-Transfer Quenching by Boron-Nitrogen Adducts in Fluorescent Sensors. J. Phys. Chem. B. 107(47): 12942-12948.

Furukawa, H; Yaghi, OM (2009). Storage of Hydrogen, Methane, and Carbon Dioxide in 
Highly Porous Covalent Organic Frameworks for Clean Energy Applications. J. Am. Chem. Soc., 131: 8875-8883.

Gopalakrishnan, M; Thirumoorthy, K; Bhuvanesh, NSP; Palanisami, N (2016). Eight membered cyclic-borasiloxanes: synthesis, structural, photophysical, steric strain and DFT calculations $\dagger$. RSC Adv. 6: 55698-55709.

Zhou, H; Long, JR; Yaghi, OM (2012). Introduction to Metal - Organic Frameworks. Am. Chem. Soc. (ACS), 112: 673-674.

Hanak, DP; Anthony, EJ; Manovic, V (2015). A review of developments in pilot-plant testing and modelling of calcium looping process for $\mathrm{CO} 2$ capture from power generation systems. Energy Environ Sci., 8: 2199-2249.

Hasan, MMF; Baliban, RC; Elia, JA; Floudas, CA (2012). Modeling, simulation, and optimization of postcombustion $\mathrm{CO} 2$ capture for variable feed concentration and flow rate. 1. Chemical absorption and membrane processes. Ind. Eng. Chem. Res. 51(48): 15642-15664.

Hauchhum, L., \& Mahanta, P. (2014). Carbon dioxide adsorption on zeolites and activated carbon by pressure swing adsorption in a fixed bed. Int. J. Energy Environ. Eng. 5(4): 349-356.

Held, I. (2012). Climate science: Constraints on the high end. Nature Geoscience, 5(4): 236-237.

Höpfl, H. (1999). The tetrahedral character of the boron atom newly defined-a useful tool to evaluate the $\mathrm{N} \rightarrow \mathrm{B}$ bond. J. Organomet Chem. 581(1-2), 129-149.

Hunt, JR; Doonan, CJ; Levangie, JD; Co, AP (2008). Reticular Synthesis of Covalent Organic Borosilicate Frameworks. J. Am. Chem. Soc. 130: 11872-11873. https://doi.org/10.1021/ja805064f

Hutson, ND; Speakman, SA; Payzant, EA (2004). Structural Effects on the High Temperature Adsorption of $\mathrm{CO}_{2}$ on a Synthetic Hydrotalcite. Chem. Mater. 16(21): 4135-4143.

Icli, B; Sheepwash, E; Riis-Johannessen, T; Schenk, K; Filinchuk, Y; Scopelliti, R; Severin, K (2011). Dative boron-nitrogen bonds in structural supramolecular chemistry: multicomponent assembly of prismatic organic cages. Chem. Sc. 2(9), 1719-1721.
Icli, B; Solari, E; Kilbas, B; Scopelliti, R; Severin, K (2012). Multicomponent assembly of macrocycles and polymers by coordination of pyridyl ligands to 1,4bis(benzodioxaborole)benzene. Chem.A Eur J. 18(46), 14867-14874.

Idem, R; Wilson, M; Tontiwachwuthikul, P; Chakma, A; Veawab, A; Aroonwilas, A; Gelowitz, D (2006). Pilot plant studies of the $\mathrm{CO}_{2}$ capture performance of aqueous MEA and mixed MEA/MDEA solvents at the University of Regina CO2capture technology development plant and the boundary dam CO2capture demonstration plant. Ind. Eng. Chem. Res. 45(8): 2414-2420.

Kalamaras, CM., Efstathiou, AM (2012). Hydrogen Production Technologies: Current State and Future Developments. Hydrogen Production Technologies: Current State and Future Developments, 2013: 1-9.

Kato, M; Nakagawa, K; Essaki, K; Maezawa, Y; Takeda, S; Kogo, R; Hagiwara, Y (2005). Novel $\mathrm{CO}_{2}$ absorbents using lithium-containing oxide. Int. J. Appl. Ceram. Tech. 2(6): 467-475.

Konieczny, A; Mondal, K; Wiltowski, T; Dydo, P (2008). Catalyst development for thermocatalytic decomposition of methane to hydrogen. Int. J. Hydrog Energy 33(1): 264-272.

Krishna, R., van Baten, J. M. (2010). In silico screening of zeolite membranes for $\mathrm{CO}_{2}$ capture. J. Membr Sci. 360(1-2): 323-333.

Kua, J; Fletcher, MN; Iovine, PM (2006). Effect of para-substituents and solvent polarity on the formation of triphenylboroxine. amine adducts. $J$. Phys. Chem. A. 110(26): 8158-8166.

Lackner, KS (2010). Comparative Impacts of Fossil Fuels and Alternative Energy Sources. Environ. Sci. Tech, 29: 1-40.

Langlois, P; Pentchev, I; Hinkov, I; Lamari, FD; Langlois, P; Dicko, M; Chilev, C; Pentchev, I (2016). Carbon Dioxide Capture By Adsorption. J. Chem. Tech. Metallur. 51(6): 609-627.

Lappert, MF (1956). Organic Compounds Of Boron. Chemical Reviews, 56(5), 959-1064.

Li, H; Wang, K; Sun, Y; Lollar, CT; Li, J; Zhou, HC (2017). Recent advances in gas storage and 
separation using metal-organic frameworks. Materials Today, 21(2): 108-121.

Li, J; Ma, Y., Mccarthy, M. C., Sculley, J., Yu, J., Jeong, H., Balbuena, P. B., \& Zhou, H. (2011). Carbon dioxide capture-related gas adsorption and separation in metal-organic frameworks. Coordination Chemistry Reviews, 255(15-16), 1791-1823.

Li, J. R., Ma, Y; McCarthy, MC; Sculley, J; Yu, J; Jeong, HK; Balbuena, PB; Zhou, HC. (2011). Carbon dioxide capture-related gas adsorption and separation in metal-organic frameworks. Coord. Chem. Rev. 255(15-16): 1791-1823.

Li, J; Sculley, J; Zhou, H. (2012). Metal À Organic Frameworks for Separations. Chem. Rev., 112: 869-932

Li, N; Hao, M; Phalen, RF; Hinds, WC; Nel, AE (2003). Particulate air pollutants and asthma: A paradigm for the role of oxidative stress in PMinduced adverse health effects. Clinical Immunology, 109(3): 250-265.

Lin, SH; Shyu, CT (2000). Carbon dioxide absorption by amines: System performance predictions and regeneration of exhausted amine solution. Environ. Tech. (United Kingdom). 21(11), 12451254.

Lindskog, S; Coleman, JE (1973). The catalytic mechanism of carbonic anhydrase. Proceedings of the National Academy of Sciences of the United States of America, 70(9): 2505-2508.

Liu, W; Pink, M; Lee, D (2009). Conjugated Polymer Sensors Built on $\pi$-Extended Borasiloxane Cages. J. Am. Chem. Soc. 131: 8703-8707.

Martín, CF; Stöckel, E; Clowes, R; Adams, DJ; Cooper, AI; Pis, JJ; Rubiera, F; Pevida, C (2011). Hypercrosslinked organic polymer networks as potential adsorbents for pre-combustion $\mathrm{CO}_{2}$ capture. J. Mater Chem. 21(14), 5475-5483.

Merel, J; Clausse, M; Meunier, F (2008). Experimental investigation on $\mathrm{CO} 2$ post-combustion capture by indirect thermal swing adsorption using $13 \mathrm{X}$ and 5A zeolites. Ind. Eng. Chem. Res. 47(1): 209-215.

Millward, AR; Yaghi, OM (2005). Metal-organic frameworks with exceptionally high capacity for storage of carbon dioxide at room temperature. $J$. Am. Chem. Soc. 127(51): 17998-17999.
Mirela P; Albert R (2013). Synthesis of borasiloxanebased macrocycles by multicomponent condensation reactions in solution or in a ball mill†t. Chem Comm. 49:45-47.

Muradov, NZ (1993). How to produce hydrogen form fossil fuels without $\backslash$ ce $\{\mathrm{CO} 2\}$ emission. Int. J. Hydrog Energy. 18(3): 211-215.

O’Dowd, AT; Spalding, TR; Ferguson, G; Gallagher, JF; Reed, D (1993). Synthesis and crystal structure of the novel borosilicate cage compound [B(OSiPh2OSiPh2O)3B]. J. Chem. Soc. ChemComm, 634(24): 1816-1817.

Ochoa-Fernández, E; Rønning, M; Grande, T; Chen, D (2006). Synthesis and $\mathrm{CO}_{2}$ capture properties of nanocrystalline lithium zirconate. Chem. Mater. 18(25): 6037-6046.

Olajire, AA (2017). Recent advances in the synthesis of covalent organic frameworks for $\mathrm{CO} 2$ capture. Biochem. Pharmaco. 17, 137-161.

Onozaki, M; Watanabe, K; Hashimoto, T; Saegusa, H; Katayama, Y (2006). Hydrogen production by the partial oxidation and steam reforming of tar from hot coke oven gas. Fuel. 85(2): 143-149.

Panel, I; Change, C (2005). Carbon Dioxide Capture and Storage. IPCC Special Report. https://www.ipcc.ch/pdf/special-

Puthiaraj, P; Cho, SM; Lee, YR.; Ahn, WS (2015). Microporous covalent triazine polymers: efficient Friedel-Crafts synthesis and adsorption/storage of $\mathrm{CO}_{2}$ and $\mathrm{CH}_{4}$. J. Mater Chem. A. 3(13), 67926797

Xu, R; Pang, W; Yu, J; Chen, J (2007). Chemistry of zeolites and related porous materials: synthesis and structure. John Wiley and Sons, Inc.

Rackley, SA (2010). Carbon Capture and Storage. Elsevier.

Rangnekar, N; Mittal, N; Elyassi, B; Caro, J; Tsapatsis, M (2015). Chem Soc Rev Zeolite membranes - a review and comparison with MOFs. Chem.l Soc. Rev. 44: 7128-7154.

Raupach, MR; Marland, G; Ciais, P; Le-Quere, C; Canadell, JG; Klepper, G; Field, CB (2007). Global and regional drivers of accelerating $\mathrm{CO}_{2}$ emissions. Proceedings of the National Academy of Sciences, 104(24), 10288-10293. 
Reddy, MKR., Xu, ZP; Lu, GQ; Da- Costa, JCD (2006). Layered double hydroxides for CO2 capture: Structure evolution and regeneration. Ind. Eng. Chem. Res, 45(22), 7504-7509.

Reza, J; Trejo, A (2006). Degradation of aqueous solutions of alkanolamine blends at high temperature, under the presence of $\mathrm{CO}_{2}$ and $\mathrm{H}_{2} \mathrm{~S}$. Chem. Eng. Comm, 193(1), 129-138.

Riboldi, L., \& Bolland, O. (2015). Evaluating Pressure Swing Adsorption as a $\mathrm{CO}_{2}$ separation technique in coal-fired power plants. Int. J. Greenh. 39, 116

Rochelle, GT (2009). Amine scrubbing for $\mathrm{CO}_{2}$ capture. Science (New York, N.Y.), 325(5948): 1652-1654.

Rostrup-Nielsen, JR; Rostrup-Nielsen, T (2002). Large-scale hydrogen production. Cattech, 6(4): $150-159$.

Sa, M; Santillan, R; Rojas-lima, S (2002). Facile Preparation of [4.4]Metacyclophane- and [5.5]Paracyclophane-Type Macrocycles from Arylboronic Acids and Salicylideneaminoaryl Alcohols. Chem. Eur. J. 8(3), 612-621.

Sabouni, R., Kazemian, H., \& Rohani, S. (2014). Carbon dioxide capturing technologies: A review focusing on metal organic framework materials (MOFs). Environ. Sci. Pollut. Res. 21(8): 54275449

Salazar-Mendoza, D; Guerrero-Alvarez, J; Höpfl, H (2008). 3-Pyridineboronic acid $\rightarrow$ boroxine $\rightarrow$ pentadecanuclear boron cage $\rightarrow 3 \mathrm{D}$ molecular network: a sequence based on two levels of selfcomplementary self-assembly. ChemComm. 48(48), 6543

Santillan, R; Gutie, A; Barba, V (2005). Macrocycles , adducts and monomeric boron compounds derived from 2 , 6-dimethanolpyridine and arylboronic acids. Inorganica. Chim. Acta, 358: 2996-3002.

Seinfeld, JH (2011). Insight on global warming. AIChE J. 57(12), 3259-3284.

Shakerian, F; Kim, KH; Szulejko, JE; Park, JW (2015). A comparative review between amines and ammonia as sorptive media for postcombustion $\mathrm{CO}_{2}$ capture. Applied Energy, 148:
$10-22$.

Sheepwash, E; Krampl, V; Scopelliti, R; Sereda, O; Neels, A; Severin, K (2011). Molecular networks based on dative boron-nitrogen bonds. Angew. Chem. - Int. Ed. 50: 3034-3037.

Sheepwash, E; Zhou, K; Scopelliti, R; Severin, K (2013). Self-assembly of arylboronate esters with pyridyl side chains. Eur J. Inorg Chem. 2013(14): 2558-2563

Shekh, AY; Krishnamurthi, K; Mudliar, SN; Yadav, RR; Fulke, AB; Devi, SS Chakrabarti, T (2012). Recent advancements in carbonic anhydrasedriven processes for COSequestration: Minireview. Critical Reviews in Environmental Science and Technology, 42(14), 1419-1440.

Silverman, DN; Lindskog, S (1988). The Catalytic Mechanism of Carbonic Anhydrase: Implications of a Rate-Limiting Protolysis of Water. Acc. Chem. Res. 21(1), 30-36.

Slaughter, JC; Kim, E; Sheppard, L; Sullivan, JH; Larson, TV; Claiborn, C (2005). Association between particulate matter and emergency room visits, hospital admissions and mortality in Spokane, Washington. J. Expo. Anal. Environ. Epidem. 15(2), 153-159.

Sneddon, G; Greenaway, A; Yiu, HH (2014). The Potential Applications of Nanoporous Materials for the Adsorption, Separation, and Catalytic Conversion of Carbon Dioxide. 4: 1-19.

Spitler, EL; Koo, BT; Novotney, JL; Colson, JW; Uribe-Romo, FJ; Gutierrez, GD; Clancy, P; Dichtel, WR (2011). A 2D covalent organic framework with 4.7-nm pores and insight into its interlayer stacking. J. Am. Chem. Soc. 133: 19416-19421

Stewart, C; Hessami, MA (2005). A study of methods of carbon dioxide capture and sequestration - The sustainability of a photosynthetic bioreactor approach. Energy Conver. Manage. 46(3): 403420.

Sumida, K; Rogow, DL; Mason, JA; McDonald, TM; Bloch, ED; Herm, ZR; Bae, TH; Long, JR (2012). Carbon dioxide capture in metal-organic frameworks. Chem. Rev. 112(2): 724-781. https://doi.org/10.1021/cr2003272

Timokhin, I; Baguña Torres, J; White, AJP; Lickiss, 
PD; Pettinari, C; Davies, RP (2013). Organosilicon linkers in metal organic frameworks: the tetrahedral tetrakis(4tetrazolylphenyl)silane ligand. Dalton Transactions (Cambridge, England: 2003): 42(38): 13806-13808.

Torres-huerta, A: Jesu, MD; Mart, D; Ho, H; Jancik, V (2017). Structural Induction via Solvent Variation in Assemblies of Triphenylboroxine and Piperazine Potential Application as SelfAssembly Molecular Sponge. Cryst Growth Des. 17, 2438-2452.

Trachtenberg, M. C., Cowan, R. M., Smith, D. A., Horazak, D. A., Jensen, M. D., Laumb, J. D., Vucelic, A. P., Chen, H., Wang, L., \& Wu, X. (2009). Membrane-based, enzyme-facilitated, efficient carbon dioxide capture. Energy Procedia, 1(1), 353-360. https://doi.org/10.1016/j.egypro.2009.01.048

Trenberth, Kelvin E. (2009). Changes in the Flow of Energy through the Earth's Climate System. Physics and Society, 38(2), 11-16.

Trenberth, Kevin E., Fasullo, J. T., Kiehl, J., Trenberth, K. E., Fasullo, J. T., \& Kiehl, J. (2009). Earth's Global Energy Budget. Bulletin of the American Meteorological Society, 90(3), 311-324

United, Nations, NYT. (2008). World Population Prospects The 2008 Revision Highlights. World
Population Prospects.

United Nations: Department of Social and Economic Affairs. (n.d.). World population prospects: The 2012 revision, DVD edition. Population Division 2013, http://esa.un.org/unpd/wpp/ExcelData/population.h.

United Nations / Department of Economic and Social Affairs. (2009). World Population Prospects : The 2008 Revision. Population Newsletter, 87: 1-20.

Verdegaal, WM; Wang, K; Sculley, JP; Wriedt, M; Zhou, HC (2016). Evaluation of Metal-Organic Frameworks and Porous Polymer Networks for $\mathrm{CO}_{2}$-Capture Applications. ChemSusChem. 9(6): 636-643

Yadav, RR; Krishnamurthi, K; Mudliar, SN; Devi, SS; Naoghare, PK.; Bafana, A; Chakrabarti, T (2014). Carbonic anhydrase mediated carbon dioxide sequestration: Promises, challenges and future prospects. J. Basic Microbiol, 54(6): 472-481.

Yu, C. H., Huang, C. H., \& Tan, C. S. (2012). A review of $\mathrm{CO} 2$ capture by absorption and adsorption. Aerosol and Air Quality Research, 12(5), 745769

Yuan, B; Ma, D; Wang, X; Li, Z; Li, Y; Liu, H; He, D; (2012). A microporous, moisture-stable, and amine-functionalized metal-organic framework for highly selective separation of $\mathrm{CO}_{2}$ from $\mathrm{CH}_{4}$. Chem. Commun., 48(8), 1135-1137. 